\title{
Pertumbuhan dan Hasil Beberapa Calon Klon Tanaman Iles-Iles (Amorphophallus muelleri Blume)
}

\section{Growth and Production of Some Candidate New Clones Iles-Iles (morphophallus $\underline{\text { muelleri Blume) }}$}

\author{
Siska Rosdiana dan Edi Santosa* \\ Departemen Agronomi dan Hortikultura, Fakultas Pertanian, Institut Pertanian Bogor \\ (Bogor Agricultural University), Jl. Meranti, Kampus IPB Darmaga, Bogor 16680, Indonesia \\ Telp. \& Faks.62-251-8629353 e-mail : agrohort@apps.ipb.ac.id \\ *Penulis Korespondensi : edisang@gmail.com \\ Disetujui : 30 Oktober 2018 / Published Online 06 Mei 2019
}

\begin{abstract}
Evaluations on growth and production of iles-iles accessions are important in the development of candidate clone of Amorphophallus muelleri Blume. The objective of study was to evaluate the growth and productivity of four accessions as candidate of new superior clones. The study was conducted at IPB Leuwikopo Farm Bogor, West Java, from August 2017 to May 2018. This study used a single factor in Completely Randomized Group Design (CRGD) method using iles-iles accessions from IPB selection. The results indicated that the growth characters of SB, SGH, SGBKK, and STS accessions had no marked different. The accessions exhibited variation in leaf characters. The first leaf showed statistically different in petiol length, number of leaflets and canopy width. Yield component exhibited variation in corm length, while the other components showed statistically similar. Considering the highest corm weight of SB and STS accessions, these accessions are recommended for further evaluation.
\end{abstract}

Keywords: accession, corm production, genetic, pest and disease, porang

\begin{abstract}
ABSTRAK
Evaluasi pertumbuhan dan produksi aksesi tanaman iles-iles sangat penting dilakukan dalam rangka mendapatkan suatu calon klon unggul baru. Tujuan penelitian adalah mengevaluasi pertumbuhan dan hasil empat aksesi iles-iles sebagai calon klon unggul baru. Penelitian dilakukan di Kebun Percobaan Leuwikopo, IPB Dramaga, Bogor, Jawa Barat pada bulan Agustus 2017 sampai Mei 2018. Penelitian ini menggunakan metode Rancangan Kelompok Lengkap Teracak (RKLT) faktor tunggal aksesi iles-iles hasil seleksi IPB. Hasil penelitian menunjukkan bahwa karakter pertumbuhan iles-iles pada aksesi SB, SGH, SGBKK dan STS secara umum tidak berbeda nyata. Perbedaan pertumbuhan keempat aksesi dijumpai pada daun pertama. Daun pertama juga menunjukkan perbedaan pada jumlah anak daun, panjang petiol dan lebar kanopi. Peubah yang diamati pada komponen hasil tidak menunjukkan nilai yang berbeda nyata kecuali pada tinggi umbi. Berdasarkan potensi hasil umbi iles-iles tertinggi, aksesi SB dan STS direkomendasikan untuk dikaji lebih mendalam dalam rangka menghasilkan klon iles-iles baru dengan hasil yang lebih unggul.
\end{abstract}

Kata kunci: aksesi, genetik, hama dan penyakit, porang, produksi umbi 


\section{PENDAHULUAN}

Tanaman iles-iles (Amorphophallus muelleri Blume) dikenal sebagai porang, coplok atau lotrok oleh masyarakat Indonesia (Sugiyama dan Santosa, 2008; Sulistiyo et al., 2015). Tanaman ini merupakan tanaman asli Jawa, Indonesia (Jansen et al., 1996). Tanaman Amorphophallus biasa ditanam secara tumpangsari atau tumbuh liar di hutan-hutan (Santosa et al., 2005; Sugiyama dan Santosa, 2008; Santosa, 2014; Santosa dan Sugiyama, 2016).

Umbi iles-iles mengandung glukomannan yakni sejenis karbohidrat rantai panjang yang sulit dicerna. Umbi iles-iles merupakan sumber glukomannan baru, memiliki kualitas sama dengan glukomannan dari Amorphophallus konjac yang banyak dibudidayakan di Jepang, China dan Korea. Glukomannan dari A. konjac di Jepang dimanfaatkan sebagai bahan baku pembuatan konyaku dan oden (makanan khas Jepang). Selain untuk bahan makanan, glukomannan telah banyak digunakan sebagai bahan baku industri obat pelangsing, pembungkus yang edible dan filler obat karena sifat koloid yang istimewa dengan kandungan energi yang rendah (Sugiyama dan Santosa, 2008).

Perbanyakan klon iles-iles dapat dilakukan dengan bulbil, kulit umbi (Santosa dan Wirnas, 2009) dan biji. Perlakuan agronomis yang tepat akan meningkatkan hasil klon iles- iles (Sugiyama dan Santosa, 2008; Santosa et al., 2011).

Di antara keunggulan tersebut, masih ada masalah mendasar pada iles-iles yakni produktivitas yang rendah. Produktivitas iles-iles rata-rata yaitu 6-12 ton ha $^{-1}$ umbi basah (Pusat PKKP, 2013). Sugiyama dan Santosa (2008) menyatakan bahwa potensi produksi iles- iles $>40$ ton ha ${ }^{-1}$. Rendahnya produktivitas tanaman ilesiles tersebut, disebabkan oleh beberapa hal diantaranya: 1) rendahnya potensi genetik klon tanaman yang ada, 2) teknik budidaya yang masih belum intensif dan masih bergantung pada panen alam dan 3) kurangnya pemahaman mengenai waktu panen yang tepat. Berbeda dengan aspek budidaya yang sudah banyak diteliti, perbaikan genetika iles-iles masih belum banyak dikaji.

Peningkatan produktivitas dapat menggunakan pendekatan agronomis (Sugiyama dan Santosa, 2008; Santosa et al., 2011), iradiasi sinar gamma (Santosa et al., 2014) dan pemberian hormon. Peningkatan produktivitas melalui perbaikan genetik belum pernah dilakukan, termasuk di Indonesia. Iles-iles merupakan tanaman apomiksis, dimana pembentukan biji tanpa melalui penyerbukan
(Jansen et al., 1996). Tetapi, Santosa et al. (2018) melaporkan adanya keragaman morfologi. Implikasinya, perakitan varietas baru dapat di tempuh melalui seleksi klonal yang memiliki karakter produksi tinggi. Melalui kegiatan seleksi klonal di IPB Dramaga, telah di peroleh beberapa aksesi sebagai calon klon baru iles-iles. Calon klon-klon tersebut yang di evaluasi pada penelitian ini.

Evaluasi dan identifikasi karakter pertumbuhan tanaman sangat penting dilakukan dalam pengujian suatu calon klon. Evaluasi tersebut adalah memilih satu atau beberapa calon klon yang memiliki sifat-sifat unggul yang diharapkan dalam upaya peningkatan produksi dan dapat diusulkan sebagai kultivar unggul baru. Santosa et al. (2016) menyatakan bahwa idiotipe iles-iles yang mampu berproduktivitas tinggi antara lain: responsif terhadap pemupukan, mampu melewati masa dormansi, bulking ratio tinggi, jumlah daun banyak, ukuran daun besar dan kandungan bahan kering tinggi. Tujuan penelitian adalah mengevaluasi pertumbuhan dan hasil empat aksesi iles-iles sebagai calon klon unggul baru.

\section{BAHAN DAN METODE}

Penelitian ini dilaksanakan pada bulan Agustus 2017 hingga bulan Mei 2018 di Kebun Percobaan Leuwikopo (245 m dpl), Departemen Agronomi dan Hortikultura, Fakultas Pertanian, Institut Pertanian Bogor, Bogor, Jawa Barat.

Bahan yang digunakan adalah umbi iles-iles (Amorphophallus muelleri Blume) yang diperoleh dari koleksi Kebun Percobaan Leuwikopo berumur 1 tahun. Aksesi yang digunakan sebanyak 4 aksesi yaitu SB, SGH, SGBKK dan STS yang ditanam dalam empat ulangan. Pupuk yang digunakan berupa pupuk $\mathrm{N}$, pupuk $\mathrm{P}_{2} \mathrm{O}_{5}$, pupuk $\mathrm{K}_{2} \mathrm{O}$ dengan dosis berturut-turut 100:60:80 ha ${ }^{-1}$ dan pupuk kandang sapi 40-45 $\mathrm{kg}$ per bedengan. Bahan penunjang lainnya berupa kantong plastik, kertas dan label.

Alat yang digunakan dalam penelitian ini adalah alat pengolah tanah, alat penanaman, penyiangan dan panen. Alat yang digunakan dalam pengamatan yaitu jangka sorong digital, meteran, timbangan digital, kamera dan alat tulis.

Penelitian ini menggunakan metode Rancangan Kelompok Lengkap Teracak (RKLT) faktor tunggal. Jumlah tanaman ulangan per aksesi yang di tanam berbeda-beda. Umbi aksesi SB ditanam sebanyak 56, 20, 20 dan 54; umbi SGH sebanyak 52, 20, 20 dan 52; umbi SGBKK sebanyak 87, 26, 26 dan 84; umbi STS sebanyak $60,26,27$ dan 60 berurutan pada ulangan satu, 
dua, tiga dan empat. Perbedaan jumlah umbi yang ditanam di tiap aksesi dan ulangan dikarenakan adanya penyesuaian dengan luas bedengan tiap ulangan dan jumlah bahan tanam yang tersedia di koleksi Kebun Percobaan Leuwikopo IPB.

Lahan seluas $90 \mathrm{~m}^{2}$ diolah menggunakan traktor dan cangkul. Lahan menggunakan naungan paranet dengan intensitas cahaya 55\%. Bedengan dibuat berukuran $1 \times 6 \mathrm{~m}$ untuk ulangan I dan IV, sedangkan ulangan II dan III berukuran $1 \times 4 \mathrm{~m}$.

Penanaman menggunakan umbi yang berdimensi $3 \mathrm{~cm}$ sampai $12 \mathrm{~cm}$, dengan jarak tanam $50 \times 50 \times 50 \mathrm{~cm}$ (disesuaikan dengan dimensi umbi) dan ditanam dari dimensi terbesar hingga terkecil di setiap bedengan dengan menggunakan sistem tanam Jepang yaitu penanaman dilakukan di bagian cekungan bedengan.

Pemeliharaan tanaman iles-iles meliputi pengendalian gulma dan pemupukan. Pengendalian gulma dilakukan secara manual dengan cara menyiangi gulma di sekitar tanaman. Pengendalian gulma tidak menggunakan herbisida dikarenakan herbisida dapat mengganggu pertumbuhan tanaman iles-iles. Pemupukan dilakukan saat pertanaman berumur 10 Minggu Setelah Tanam (MST) dan 20 MST dengan dosis pupuk NPK masing-masing setengahnya.

Pengamatan tanaman iles-iles dilakukan mulai 1 MST sampai 22 MST. Parameter pertumbuhan tanaman iles-iles yang diamati meliputi daya tumbuh, jumlah daun, jumlah anak daun, diameter petiol dan lebar kanopi. Panen umbi dilakukan pada 35 MST, yakni saat semua daun telah menguning dan kering. Umbi dipanen dan dikumpulkan menurut masing-masing aksesi. Komponen hasil yang diamati meliputi diameter umbi, tinggi umbi, bobot umbi, bentuk umbi dan kesehatan umbi.

Data hasil pengamatan diolah dengan uji $\mathrm{F}$ pada taraf 5\% menggunakan aplikasi SAS untuk mengetahui pengaruh perlakuan. Jika hasil uji $\mathrm{F}$ berbeda nyata maka dilakukan uji lanjut beda nyata jujur (BNJ) atau honest significant different (HSD) pada selang kepercayaan 5\%.

\section{HASIL DAN PEMBAHASAN}

\section{Kondisi Umum}

Penanaman tanaman iles-iles dilakukan saat memasuki musim hujan yaitu bulan Agustus 2017 dengan curah hujan bulanan berkisar $178.8 \mathrm{~mm}$. Suhu pada saat penanaman berkisar $25.8{ }^{\circ} \mathrm{C}$ dengan tingkat kelembaban 66\%. Pada saat panen bulan April, curah hujan bulanan mencapai 353.4 mm dengan suhu sekitar $25.2^{\circ} \mathrm{C}$ dan tingkat kelembaban udara 93\% (BMKG, 2018).
Pertumbuhan tanaman iles-iles secara umum tergolong baik. Pengendalian gulma dilakukan setiap minggu secara manual yaitu menyiangi gulma di sekitar tanaman. Gulma yang tumbuh di lahan penelitian antara lain Caladium bicolor, Ageratum conyzoides, Borreria alata dan Rottboellia exaltata. Hama yang banyak dijumpai menyerang pertanaman iles-iles di lapangan yaitu ulat dan belalang. Pengendalian hama tersebut dilakukan secara manual dengan cara mengambil ulat maupun belalang dan mengumpulkannya di plastik untuk kemudian dibuang ditempat yang jauh dari pertanaman iles-iles. Kutu kebul (Bemisia tabaci) juga ditemukan menyerang daun, dikendalikan dengan cara dibersihkan secara manual dengan cara mengelap permukaan daun yang terserang. Selain hama yang menyerang, juga ditemukan adanya musuh alami hama yaitu belalang sembah (Mantidae sp.).

Penyakit yang menyerang tanaman iles-iles di lapangan yaitu busuk pangkal petiol (Sclerotium sp.) sebanyak $4.2 \%$ tanaman dari total 654 tanaman yang diamati. Penyakit ini terjadi saat musim hujan yang lebat disertai dengan cuaca panas selama \pm 3 hari berturut-turut. Selain itu, pada pertanaman ulangan 1 dan 3 terdapat daun iles-iles yang terbakar (sunburn symptoms). Hal tersebut dikarenakan tanaman berada di bawah paparan sinar matahari yang terus-menerus walaupun sudah di beri naungan paranet $55 \%$. Daun yang terbakar menunjukkan gejala kerusakan pada daun dan tepi daun menggulung, hal ini sesuai dengan pernyataan Santosa et al. (2006).

\section{Daya Berkecambah Iles-Iles}

Daya berkecambah iles-iles mulai di hitung ketika tunas muncul ke permukaan tanah dan masih terbungkus oleh seludang sampai 15 MST. Tunas yang berasal dari umbi mulai muncul pada 7-15 MST. Menurut Turhadi dan Indriyani (2015), kecambah benih mulai muncul antara 1-6 MST, artinya, perkecambahan tunas yang berasal dari umbi lebih lama dibandingkan dengan perkecambahan iles-iles yang berasal dari benih. Hidayat et al. (2018) menyatakan bahwa pada 46 hari setelah tanam daya tumbuh iles-iles asal biji mencapai $>91 \%$.

Persentase daya kecambah umbi iles di lapangan di keempat aksesi setelah dilakukan uji $\mathrm{F}$ taraf 5\% menunjukkan nilai yang berbeda nyata (data tidak dicantumkan). Perkecambahan tunas keempat aksesi disajikan dalam bentuk diagram garis (Gambar 1).

Gambar 1 menunjukkan bahwa aksesi STS mengalami perkecambahan lebih lambat daripada aksesi SB, SGH dan SGBKK. Awal 
perkecambahan keempat aksesi memiliki daya kecambah yang relatif sama. Akhir pengamatan, terlihat bahwa daya kecambah iles-iles dari empat aksesi memiliki daya kecambah yang hampir sama pada saat 14-15 MST. Ada kemungkinan aksesi STS memiliki masa dormansi umbi yang lebih lama dibandingkan dengan aksesi lainnya. Sehingga, pertumbuhan aksesi STS lebih lambat dari ketiga aksesi lainnya.

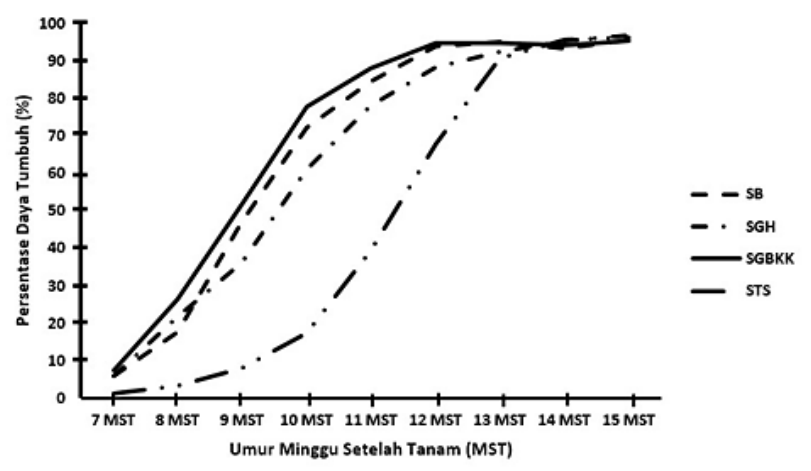

Gambar 1. Presentase daya kecambah umbi iles-iles

\section{Morfologi Daun}

Daun iles-iles memiliki variasi warna dari hijau muda sampai hijau tua, hal ini sesuai dengan hasil penelitian Sumarwoto (2005). Permukaan daun iles-iles bergelombang halus dan tepi daun memiliki variasi warna saat pertumbuhannya. Tepi daun muda berwarna merah muda kemudian berubah menjadi hijau saat daun berumur 3-4 minggu setelah membuka dan berwarna kuning saat daun $>5$ minggu. Terdapat perbedaan warna daun iles-iles saat berumur muda sampai tua. Helai anak daun muda iles-iles berwarna hijau kekuningan-hijau muda, daun berubah jadi berwarna hijau dan daun berwarna hijau tua pada saat dewasa. Namun demikian, tidak ada perbedaan warna daun antar aksesi yang diamati. Sulistiyo et al. (2015), menyatakan bahwa daun tanaman iles-iles tidak menunjukkan adanya keragaman. Pada penelitian ini, semua tanaman iles-iles yang diamati memiliki tipe daun majemuk menjari.

Berdasarkan penelitian Jansen et al. (1996), Amorphophallus merupakan tanaman tahunan yang memiliki daun tunggal. Namun pada penelitian ini, banyak umbi yang memiliki lebih dari satu daun. Perbedaan tersebut kemungkinan karena nutrisi umbi berbeda. Daun baru umumnya muncul dalam satu umbi setelah daun pertama berumur tua. Hal ini sesuai dengan Sugiyama dan Santosa (2008) yang menyatakan bahwa daun kedua iles-iles berkembang setelah daun pertama mengalami pertumbuhan maksimal terutama bila umbi yang ditanam berukuran sekitar 100 g. Begitu pula banyak umbi yang menghasilkan daun ketiga setelah daun kedua tumbuh maksimal.

Aksesi iles-iles yang diamati secara umum memiliki daun sebanyak 1-2 daun tiap umbi, jumlah daun terbanyak ditemukan pada satu tanaman dari aksesi SGBKK di ulangan satu dan 2 tanaman aksesi SGH ulangan empat sebanyak 3 daun tiap umbi. Berdasarkan uji $\mathrm{F}$ taraf 5\% jumlah daun tanaman iles-iles menunjukkan nilai yang tidak berbeda nyata (Tabel 1).

Tabel 1. Sidik ragam komponen vegetatif tanaman iles-iles

\begin{tabular}{lcc}
\hline Peubah & $\begin{array}{c}\text { Koef. } \\
\text { Keragaman }\end{array}$ & $\begin{array}{c}\mathrm{F} \\
\text { Hitung }\end{array}$ \\
\hline Jumlah daun & 11.1 & tn \\
Jumlah anak daun pertama & 3.6 & $*$ \\
Jumlah anak daun kedua & 3.7 & $*$ \\
Jumlah anak daun maksimal & 4.0 & $*$ \\
Lebar kanopi daun pertama & 2.6 & $*$ \\
Lebar kanopi daun kedua & 4.2 & tn \\
Panjang petiol daun pertama & 4.5 & $*$ \\
Panjang petiol daun kedua & 6.9 & tn \\
Diameter petiol daun & 5.5 & tn \\
pertama & & \\
Diameter petiol daun kedua & 7.3 & tn \\
\hline
\end{tabular}

Keterangan : tanda * menunjukkan nilai yang berbeda nyata, tanda ${ }^{\text {tn }}$ menunjukkan nilai yang tidak berbeda nyata, nilai berdasarkan uji F taraf $\alpha=5 \%$.

Pertumbuhan dan perkembangan tanaman iles-iles sangat dipengaruhi oleh faktor lingkungan misalnya curah hujan, $\mathrm{pH}$, struktur tanah dan naungan (Sugiyama dan Santosa, 2008). Selain faktor lingkungan, kemungkinan ada interaksi dengan faktor genetik aksesi ilesiles yang memengaruhi pertumbuhan dan perkembangannya.

Tanaman iles-iles aksesi STS pada ulangan satu memiliki pertumbuhan morfologi yang berbeda dari tanaman iles-iles lainnya dalam satu aksesi. Petiol iles-iles tidak memiliki corak dan pada permukaan daun terdapat bercak atau semburat putih. Fenomena tersebut mirip kasus kimera.

Jumlah tanaman yang diamati sebanyak 654 tanaman. Pertumbuhan daun kedua terjadi pada 125 tanaman sehingga hanya 19\% dari total tanaman. Jumlah total daun pada keempat aksesi iles-iles secara umum memiliki jumlah yang hampir sama. Jumlah daun terbanyak yaitu pada aksesi SB dan terendah pada STS (Tabel 2).

Daun iles-iles memiliki anak daun yang bervariasi jumlahnya. Uji $\mathrm{F}$ taraf $5 \%$ pada jumlah anak daun pertama dan kedua menunjukkan nilai yang berbeda nyata (Tabel 1). Hal tersebut diduga karena jumlah anak daun pertama maupun kedua pada empat aksesi yang di uji memiliki jumlah yang bervariasi. Nilai rataan jumlah anak daun 
tertinggi sebesar 43.4 pada aksesi STS, namun tidak berbeda nyata dengan aksesi SB. Nilai rataan terendah yaitu 37.2 pada aksesi SGH (Tabel 2).

Tabel 2. Nilai tengah komponen vegetatif tanaman iles-iles

\begin{tabular}{lcrrr}
\hline \multirow{2}{*}{ Peubah } & \multicolumn{4}{c}{ Aksesi } \\
\cline { 2 - 5 } & SB & SGH & SBKK & STS \\
\hline Jumlah daun & $1.3 \mathrm{a}$ & $1.1 \mathrm{a}$ & $1.1 \mathrm{a}$ & $1.0 \mathrm{a}$ \\
Jumlah anak daun pertama & $40.1 \mathrm{ab}$ & $37.2 \mathrm{~b}$ & $39.3 \mathrm{~b}$ & $43.0 \mathrm{a}$ \\
Jumlah anak daun kedua & $43.3 \mathrm{a}$ & $38.8 \mathrm{~b}$ & $41.2 \mathrm{ab}$ & $43.4 \mathrm{a}$ \\
Jumlah anak daun maksimal & $43.4 \mathrm{a}$ & $38.9 \mathrm{~b}$ & $41.4 \mathrm{ab}$ & $43.9 \mathrm{a}$ \\
Lebar kanopi daun pertama & $69.8 \mathrm{~b}$ & $68.7 \mathrm{~b}$ & $71.2 \mathrm{ab}$ & $74.3 \mathrm{a}$ \\
Lebar kanopi daun kedua & $75.6 \mathrm{a}$ & $72.0 \mathrm{a}$ & $73.4 \mathrm{a}$ & $74.6 \mathrm{a}$ \\
Panjang petiol daun pertama & $60.5 \mathrm{~b}$ & $59.1 \mathrm{~b}$ & $61.6 \mathrm{ab}$ & $66.8 \mathrm{a}$ \\
Panjang petiol daun kedua & $70.0 \mathrm{a}$ & $64.6 \mathrm{a}$ & $65.6 \mathrm{a}$ & $68.4 \mathrm{a}$ \\
Diameter petiol daun pertama & $21.7 \mathrm{a}$ & $21.5 \mathrm{a}$ & $22.1 \mathrm{a}$ & $22.7 \mathrm{a}$ \\
Diameter petiol daun kedua & $23.5 \mathrm{a}$ & $22.8 \mathrm{a}$ & $23.3 \mathrm{a}$ & $23.1 \mathrm{a}$ \\
\hline
\end{tabular}

Keterangan : Angka yang diikuti huruf berbeda pada baris yang sama berbeda nyata berdasarkan hasil honest significant different (HSD) pada taraf $\alpha=5 \%$.

Pengujian pada jumlah anak daun maksimal menunjukkan nilai yang berbeda nyata antar aksesi (Tabel 1). Hal tersebut dapat disebabkan oleh adanya perbedaan jumlah anak daun di tiap aksesi yang cukup tinggi (Tabel 2).

Tanaman iles-iles secara umum memiliki lebar kanopi sebesar 100-150 cm. Uji F taraf 5\% yang dilakukan pada lebar kanopi menunjukkan nilai yang berbeda nyata pada daun pertama, sedangkan daun kedua menunjukkan nilai yang tidak berbeda nyata (Tabel 1).

Nilai tengah lebar kanopi daun pertama iles-iles terbesar yaitu $74.3 \mathrm{~cm}$ pada aksesi STS dan terendah pada aksesi SGH yaitu $68.7 \mathrm{~cm}$. Namun berbeda dengan daun kedua, nilai tengah lebar kanopi iles-iles terbesar yaitu $75.6 \mathrm{~cm}$ pada SB dan terendah yaitu $72.0 \mathrm{~cm}$ pada aksesi SGH (Tabel 2).

Daun iles-iles semakin melebar seiring dengan bertambahnya umur tanaman. Berdasarkan penelitian Sugiyama dan Santosa (2008), terdapat korelasi positif antara ukuran umbi dengan lebar kanopi, semakin besar umbi maka lebar kanopi semakin besar. Daun tersusun oleh banyak anak daun. Ujung anak daun iles-iles memiliki tipe meruncing (cuspidate) dan memiliki dasar yang sempit.

Ciri khas yang dapat membedakan iles-iles dengan jenis Amorphophallus lainnya yaitu adanya umbi daun (bulbil). Umbi daun (bulbil) dapat disebut pula umbi udara atau umbi katak, muncul 1-1.5 bulan setelah daun terbuka sempurna. Ukuran umbi daun bervariasi dan dipengaruhi oleh ukuran daun serta letak pada masing-masing daun. Ukuran umbi udara yang muncul pada bagian tengah rachis merupakan umbi udara yang terbesar. Pada penelitian ini, umbi daun yang telah tua berwarna coklat muda atau hitam keabuan. Tanaman yang berumur dua tahun biasanya memiliki 16-20 umbi udara. Diameter umbi udara berkisar antara $<1-5 \mathrm{~cm}$.

\section{Morfologi Batang Semu (Petiol)}

Daun iles-iles terdiri dari petiol dan helai daun. Setiap daun memiliki satu petiol. Petiol daun pertama asal umbi memiliki ukuran lebih pendek dibandingkan petiol daun kedua maupun daun ketiga. Sama halnya dengan daun, petiol daun kedua akan muncul saat petiol daun pertama telah memasuki perkembangan sempurna (mencapai umur tua).

Aksesi iles-iles yang diamati memiliki petiol dengan corak yang berbeda-beda. Corak petiol aksesi SB berbentuk permata yang cenderung lebih rapat/banyak, berbeda dengan SGBKK yang memiliki corak lebih jarangjarang. Pada aksesi SGH dan STS, terdapat garis linier memanjang diantara corak petiolnya. Petiol dari aksesi SGH memiliki garis linier yang cenderung panjang, sementara STS garis linier cenderung lebih pendek. Namun perlu klarifikasi lebih lanjut apakah perbedaan corak pada aksesi yang diamati merupakan sifat genetik atau karena faktor lain.

Panjang petiol pada empat aksesi yang diamati memiliki keragaman. Pengujian panjang petiol pertama menunjukkan nilai berbeda nyata antar aksesi, sedangkan pada daun kedua tidak menunjukkan nilai yang berbeda nyata (Tabel 1). Nilai tengah panjang petiol daun pertama keempat aksesi iles-iles terbesar yaitu $66.8 \mathrm{~cm}$ pada aksesi STS dan terendah pada aksesi SGH yaitu $59.1 \mathrm{~cm}$. Berbeda dengan daun kedua, nilai tengah panjang petiol terbesar yaitu $70.0 \mathrm{~cm}$ pada aksesi SB dan terendah pada aksesi SGH yaitu $64.6 \mathrm{~cm}$ (Tabel 2).

Diameter petiol dipengaruhi oleh umur tanaman dan jumlah daun. Secara umum, tanaman iles-iles menghasilkan daun dengan petiol yang lebih besar dengan semakin besarnya umbi. Hal tersebut sesuai dengan pernyataan Sugiyama dan Santosa (2008), bahwa diameter batang berkorelasi erat dengan diameter umbi saat tanam dan selama pertumbuhan.

Hasil uji $\mathrm{F}$ taraf $5 \%$ pada ragam diameter petiol menunjukkan bahwa diameter petiol daun pertama dan kedua tidak berbeda nyata (Tabel 1). Diameter petiol terbesar adalah $42.23 \mathrm{~mm}$ pada petiol daun pertama maupun kedua. Diameter terkecil adalah sebesar $8.55 \mathrm{~mm}$ dan $13.27 \mathrm{~mm}$ pada petiol daun pertama dan kedua. Range diameter petiol yang besar tersebut menunjukkan 
bahwa ada keragaman yang besar pada karakter diameter petiol iles-iles baik dalam maupun antar aksesi. Sedangkan, nilai tengah diameter petiol terbesar yaitu $22.7 \mathrm{~mm}$ dan $23.5 \mathrm{~mm}$ pada petiol daun pertama dan kedua secara berurutan. Nilai tengah diameter petiol terendah yaitu $21.5 \mathrm{~mm}$ dan $22.8 \mathrm{~mm}$ pada petiol daun pertama dan kedua berurutan (Tabel 2).

\section{Komponen Hasil}

Panen dilakukan pada 35 MST saat tanaman telah memasuki fase dormansi. Fase dormansi pada tanaman iles-iles ditandai dengan daun yang mulai layu. Daun pertama mulai dorman sejak 20 MST dan dorman secara menyeluruh pada 35 MST. Tanaman iles-iles yang mulai dorman ditandai rebahnya petiol dan daun mulai berwarna kuning hingga berubah menjadi coklat.

Uji F keragaman diameter dan bobot ilesiles pada taraf $5 \%$ menunjukkan nilai yang tidak berbeda nyata antar aksesi (Tabel 3). Hal tersebut menunjukkan potensi produksi umbi iles- iles yang sama antar aksesi. Tinggi umbi memiliki nilai yang berbeda nyata antar aksesi, dimana SB memiliki umbi dengan ukuran tinggi terbesar. Ukuran umbi iles-iles meningkat setelah memasuki beberapa periode tumbuh, sesuai dengan pernyataan Sugiyama dan Santosa (2008), bahwa ukuran umbi iles-iles meningkat sejak terbentuk daun hingga dorman.

Tabel 3. Sidik ragam komponen umbi iles-iles

\begin{tabular}{lcc}
\hline Peubah & Koef. Keragaman F Hitung \\
\hline Bobot umbi $(\mathrm{g})$ & 12.2 & tn \\
Diameter horizontal umbi $(\mathrm{cm})$ & 3.8 & tn \\
Diameter vertikal umbi $(\mathrm{cm})$ & 3.0 & tn \\
Tinggi umbi $(\mathrm{cm})$ & 4.6 & $*$ \\
Bentuk umbi (skoring) & 9.0 & tn \\
Kesehatan umbi (skoring) & 4.5 & tn \\
\hline
\end{tabular}

Keterangan : tanda * menunjukkan nilai yang berbeda nyata, tanda tn menunjukkan nilai yang tidak berbeda nyata, nilai berdasarkan uji F taraf $\alpha=5 \%$.

Dalam satu aksesi, sebaran bobot umbi cukup tinggi. Umbi iles-iles terbesar yaitu 2182 gram pada aksesi STS dan umbi terkecil yaitu 32 gram pada aksesi SB. Nilai tengah bobot umbi tertinggi dimiliki aksesi STS, yakni 691.9 gram, tetapi tidak berbeda dengan aksesi lain (Tabel 4).

Umbi iles-iles umumnya memiliki bentuk membulat. Umbi iles-iles tidak memiliki anakan umbi (cormel). Pada penelitian ini, terdapat umbi dengan bentuk abnormal. Bentuk- bentuk umbi yang abnormal diantaranya umbi bibit masih menempel (tidak membusuk), umbi memiliki dua mata tunas utama dan terdapat umbi telah memiliki tunas pada saat panen. Namun bentuk umbi abnormal tersebut tidak terkumpul pada satu aksesi. Penyebab munculnya umbi abnormal tersebut masih perlu dikaji lebih lanjut.

Tabel 4. Nilai tengah peubah pengamatan umbi iles-iles

\begin{tabular}{|c|c|c|c|c|}
\hline \multirow{2}{*}{ Peubah } & \multicolumn{4}{|c|}{ Aksesi } \\
\hline & SB & SGH & SBKK & STS \\
\hline $\begin{array}{l}\text { Diameter horizontal } \\
\text { umbi }(\mathrm{cm})\end{array}$ & $11.9 \mathrm{a}$ & $11.3 \mathrm{a}$ & $11.1 \mathrm{a}$ & $11.5 \mathrm{a}$ \\
\hline $\begin{array}{l}\text { Diameter vertikal } \\
\text { umbi }(\mathrm{cm})\end{array}$ & $10.9 \mathrm{a}$ & $10.7 \mathrm{a}$ & $10.4 \mathrm{a}$ & $11.0 \mathrm{a}$ \\
\hline Tinggi umbi $(\mathrm{cm})$ & $7.1 \mathrm{a}$ & $6.8 \mathrm{ab}$ & $6.7 \mathrm{ab}$ & $6.4 \mathrm{~b}$ \\
\hline $\begin{array}{l}\text { Bentuk umbi } \\
\text { (skoring) }\end{array}$ & $2.5 \mathrm{a}$ & $2.5 \mathrm{a}$ & $2.5 \mathrm{a}$ & $2.6 \mathrm{a}$ \\
\hline $\begin{array}{l}\text { Kesehatan umbi } \\
\text { (skoring) }\end{array}$ & $3.7 \mathrm{a}$ & $3.5 \mathrm{a}$ & $3.3 \mathrm{a}$ & $3.5 \mathrm{a}$ \\
\hline
\end{tabular}

Keterangan : Angka yang diikuti huruf berbeda pada baris yang sama berbeda nyata berdasarkan hasil honest significant different (HSD) pada taraf $\alpha=5 \%$.

Selain abnormal dalam bentuknya, ada pula abnormalitas umbi yang disebabkan oleh kerusakan mekanis atau serangan hama dan penyakit. Jarak pemanenan yang terlalu lama dari tanaman iles-iles yang memasuki fase dorman menyebabkan umbi yang masih dalam tanah terserang nematoda. Akibat hal tersebut, umbi iles-iles mengalami kerusakan berupa terdapatnya lubang pada umbi. Kerusakan akibat rayap merupakan kerusakan sekunder, dimana kerusakan tersebut diduga terjadi akibat adanya nematoda yang menyerang umbi terlebih dahulu.

Kerusakan juga dapat disebabkan adanya goresan atau terbelah oleh alat panen pada saat pemanenan. Terdapat pula kulit umbi iles-iles yang bertekstur kasar, berbeda dengan tekstur halus pada umumnya. Perlu kajian lebih lanjut mengenai aspek hama dan penyakit pada umbi iles-iles dalam rangka memproduksi umbi sehat.

Kulit umbi iles-iles saat panen memiliki warna coklat muda atau coklat kekuningkuningan. Namun warna tersebut dalam 2 sampai 3 hari setelah pemanenan, kulit umbi berubah warna menjadi coklat keunguan. Hal tersebut terjadi akibat paparan sinar matahari yang langsung mengenai umbi. Ada kemungkinan kulit umbi cepat mengalami pigmentasi yang dipacu oleh paparan sinar matahari.

\section{Potensi Produksi}

Produksi umbi per hektar di hitung dengan cara mengkonversi rata-rata bobot umbi pada saat penelitian dengan jumlah tanaman iles-iles dalam satu hektar dengan asumsi populasi per hektar sebanyak 46243 tanaman atau 5 tanaman per meter persegi. 
Potensi produksi per $\mathrm{m}^{2}$ pada keempat aksesi tidak berbeda. Produksi terbesar yaitu pada aksesi STS dengan $3.2 \mathrm{~kg} \mathrm{~m}^{-2}$ dan tidak berbeda jauh dengan aksesi SB. Aksesi STS memiliki jumlah daun yang lebih sedikit dibandingkan aksesi SB. Sehingga, produksi ilesiles aksesi STS tertinggi diduga karena daun aksesi STS memiliki kapasitas fotosintesis yang lebih tinggi dari aksesi SB. Namun, hal tersebut perlu penelitian lebih lanjut mengenai kapasitas fotosintesis daun iles-iles.

Keempat aksesi yang diamati memiliki potensi produksi yang lebih rendah dari potensi produksi menurut Sugiyama dan Santosa (2008) yaitu $4 \mathrm{~kg} \mathrm{~m}^{-2}$. Namun, potensi hasil keempat aksesi tersebut lebih tinggi dibandingkan dengan kultivar iles-iles yang banyak dibudidayakan oleh petani saat ini.

\section{KESIMPULAN}

Pertumbuhan iles-iles pada aksesi SB, SGH, SGBKK dan STS secara umum tidak berbeda nyata. Perbedaan sangat nyata terjadi pada daya berkecambah umbi iles-iles. Daya kecambah umbi pada aksesi SGBKK lebih cepat dibandingkan ketiga aksesi lainnya. Aksesi STS memiliki daya kecambah yang paling lama dari keempat aksesi yang diamati. Perbedaan pertumbuhan keempat aksesi dijumpai pada daun pertama di keempat aksesi. Daun pertama menunjukkan perbedaan pada jumlah anak daun, panjang petiol dan lebar kanopi. Peubah yang diamati pada komponen hasil tidak menunjukkan nilai yang berbeda nyata kecuali pada tinggi umbi. Berdasarkan potensi hasil umbi iles-iles tertinggi, aksesi SB dan STS direkomendasikan untuk dikaji lebih mendalam dalam rangka menghasilkan klon iles-iles baru dengan hasil yang lebih unggul.

\section{UCAPAN TERIMAKASIH}

Terimakasih kepada Kementerian Ristekdikti, Republik Indonesia yang mendanai penelitian skema Penelitian Terapan Unggulan Perguruan Tinggi (PTUPT) Tahun Anggaran 2017 dan 2018. Tulisan adalah bagian dari skripsi penulis pertama dibimbingan oleh penulis kedua.

\section{DAFTAR PUSTAKA}

[BMKG] Badan Meteorologi Klimatologi dan Geofisika. 2018. Data Iklim Agustus 2017 April 2018. Stasiun Klimatologi Situ Gede. Bogor.
Hidayat, N., M.R. Suhartanto, E. Santosa. 2018. Pertumbuhan dan produksi benih iles-iles (Amorphophallus muelleri Blume) asal teknik budidaya yang berbeda. Bul. Agrohorti. 6(3):405-411.

Jansen, P.C.M., C. Van Der Wilk, W.L.A. Hetterscheid. 1996. Plant Resources of South-East Asia 9: Plant Yielding Non-seed Carbohydrate. Prosea Foundation. Bogor.

[Pusat PKKP] Pusat Penganekaragaman Konsumsi dan Keamanan Pangan. 2013. Budidaya Ilesiles. http://www.pusat-pkkp.bkp.pertanian. go.id/berita-357-budidaya- iles iles. html. [11 Maret 2017].

Santosa, E., N. Sugiyama, S. Hikosaka, T. Takano, N. Kubota. 2005. Intercropping practices in cacao, rubber and timber plantations in West Java, Indonesia. Jpn. J. Trop. Agr. 49(1):2129.

Santosa, E., N. Sugiyama, N. Nakata, O.N. Lee. 2006. Growth and corm production of Amorphophallus at different shading levels in Indonesia. Jpn. J. Trop. Agr. 50(2):87-91.

Santosa, E., D. Wirnas. 2009. Teknik perbanyakan cepat sumberdaya genetik iles-iles untuk mendukung percepatan komersialisasi secara berkelanjutan. Jurnal Ilmu Pertanian Indonesia. 14(2):91-96.

Santosa, E., I. Setiasih, Y. Mine, N. Sugiyama. 2011. Nitrogen and potassium applications on growth of Amorphophallus muelleri Blume. J. Agron. Indonesia. 39(2):124-130.

Santosa, E. 2014. Pengembangan tanaman iles-iles tumpangsari untuk kesejahteraan petani dan kemandirian industri pangan nasional. Risalah Kebijakan Pertanian dan Lingkungan. 1(2):73-79.

Santosa, E., S. Pramono, Y. Mine. N. Sugiyama. 2014. Gamma irradiation on growth of Amorphophallus muelleri Blume. J. Agron. Indonesia. 42(2):118-123.

Santosa, E., N. Sugiyama. 2016. Amorphophallus species in East Nusa Tenggara Islands, Indonesia. Trop. Agr. Develop. 60(1):53-57.

Santosa E., A.P. Lontoh, A. Kurniawati, M. Sari, N. Sugiyama. 2016. Assesmen keragaman morfologi iles-iles (Amorphophallus muelleri Blume) untuk perbaikan produksi. hal. 224-233. Dalam M.R. Suhartanto, M. Syukur, M. Surahman, S. Ilyas, A. Junaedi, A. Kurniawati, S. Marwiyah, H. Furqoni, F.A. Refra (eds.). Prosiding Seminar 
Nasional dan Kongres Perhimpunan Agronomi Indonesia. Bogor, 27 April 2016.

Santosa, E., N. Sugiyama, A. Kurniawati, A.P. Lontoh, M. Sari, Krisantini. 2018. Variation in floral morphology of agamosporous Amorphophallus muelleri Blume of natural and gibberellin flowerings. J. Appl. Hort. 20(1):15-29.

Sugiyama, N., E. Santosa. 2008. Edible Amorphophallus in Indonesia - Potential Crops in Agroforestry. Gadjah Mada University Press. Yogyakarta.
Sulistiyo, R.H., R. Soetopo, Damanhuri. 2015. Eksplorasi dan identifikasi karakter porang (Amorphophallus muelleri B.) di Jawa Timur. Jurnal Produksi Tanaman. 3(5):353361.

Sumarwoto. 2005. Iles-iles (Amorphophallus muelleri Blume); deskripsi dan sifat-sifat lainnya. Biodiversitas. 6(3):185-190.

Turhadi, S. Indriyani. 2015. Uji daya tumbuh porang (Amorphophallus muelleri Blume) dari berbagai variasi potongan biji. J. Biotropika. 1(3): 1-6. 